Chirurgia (2017) 112: 705-713

No. 6, November - December

Copyright@ Celsius

http://dx.doi.org/10.21614/chirurgia.112.6.705

\title{
The Effect of lloprost in the Healing of Colonic Anastomosis in Rats under Chemotherapy with Irinotecan
}

\author{
Stergios Arapoglou', Apostolos Kambaroudis', Ioannis Grivas², Georgios A. Delis ${ }^{3}$, Christos Karkos', \\ Konstantinos Ballas', Georgios Zacharioudakis', Panagiotis Petras', Michael Aftzoglou', Ioannis Gouziotis', \\ Georgios Koliakos ${ }^{4}$, Maria Karakwta ${ }^{4}$, Georgios Hahalis ${ }^{5}$
}

${ }^{1}$ Fifth Surgical Department, Medical School, Aristotle University of Thessaloniki, Thessaloniki, Greece ${ }^{2}$ Anatomy Histology and Embryology School of Veterinary Medicine, Aristotle University of Thessaloniki, Thessaloniki, Greece ${ }^{3}$ Laboratory of Pharmacology, School of Veterinary Medicine, Aristotle University of Thessaloniki, Thessaloniki, Greece ${ }^{4}$ Department of Biochemistry, Medical School, Aristotle University of Thessaloniki, Thessaloniki, Greece ${ }^{5}$ Department of Histopathology, Hippokratio General Hospital, Thessaloniki, Greece

Corresponding author: Stergios Arapoglou, MD, General Surgeon $5^{\text {th }}$ Surgical Department Aristotle University of Thessaloniki Hippokratio Hospital, 49 Konstantinoupoleos Ave Thessaloniki, Greece, 54642 E-mail: arapos1@hotmail.com

\section{Rezumat}

Efectul iliprostului în vindecarea anastomozelor colonice în contextul chimioterapiei intraperitoneale cu irinotecan într-un model murin

Scop: Am investigat posibilele efecte pozitive ale iloprostului în vindecarea anastomozelor colonice, la şobolani sub chimioterapie intraperitoneală cu irinotecan.

Metodă: Patruzeci de şobolani masculi Wistar au fost împărțiți în patru grupuri. În fiecare caz s-a practicat o colectomie parțială segmentară cu anastomoză termino-terminală. Ulterior li s-a administrat intraperitoneal, ser fiziologic (grupul 1), irinotecan (grupul 2), iloprost (grupul 3), irinotecan şi iloprost (grupul 4). Etapele următoare au constat în: autopsie, examinare macroscopică şi măsurarea presiunii de ruptură anastomotică. Un fragment al anastomozei a fost trimis pentru examen histologic şi pentru determinarea nivelurilor de hidroxiprolină.

Rezultate: Frecvența fistulei anastomotice, cât şi a formării de aderențe intraperitoneale au fost semnificativ crescute în grupul 2 comparativ cu celelalte grupuri. Presiunea de liză a anastomozei a fost semnificativ mai scăzută în grupul 2, comparativ cu toate celelalte grupuri; de asemenea, acest indicativ a fost semnificativ crescut în grupul 4 comparativ cu grupul 2. Gradul de leucocitoză, numărul de fibroblasti, nivelele de neocollagen şi hidroxiprolină din grupul 4 au fost semnificativ crescute comparativ cu grupul 
2. Angiogeneza a fost semnificativ crescută în grupurile 3 şi 4 în comparație cu grupul 2.

Concluzii: Administrarea intraperitoneală a iloprostului după colectomie segmentară cu anastomoză termino-terminală şi chimioterapie intraperitoneală cu irinotecan promovează procesul de vindecare a anastomozelor colonice, deoarece acesta concurează efectul inhibitor al irinotecanului.

Cuvinte cheie: vindecarea anastomozei colonice, irinotecan, iloprost, prostaglandine

\begin{abstract}
Purpose: We have investigated the possible positive effect of iloprost in the healing of colonic anastomosis, in rats under intraperitoneal chemotherapy with irinotecan.

Method: Forty male Wistar rats have been divided into four groups. They underwent a partial colectomy and a termino-terminal anastomosis. They were administered, intraperitoneally, saline (group 1), irinotecan (group 2), iloprost (group 3), or irinotecan and iloprost (Group 4). After the sacrifice of the animals what followed was an autopsy, a macroscopic examination and the measurement of the anastomotic rupture pressure. A portion of the anastomosis was sent over for histological examination and determination of hydroxyproline levels.

Results: The frequency of the leakage from the anastomosis was considered as significantly increased in group 2 compared with the other groups. In group 2 , a significantly greater degree of adhesions, compared to all the remaining groups, was observed. The bursting pressure of the anastomosis was significantly lower in group 2, as compared with all the remaining groups, and significantly increased in the group 4 compared with group 2. Leukocytosis, fibroblasts, the neocollagen and the levels of hydroxyproline in group 4 showed significantly increased values, compared with group 2. The angiogenesis was significantly increased in groups 3 and 4 compared with group 2.

Conclusions: Intraperitoneal administration of iloprost after colectomy, termino-terminal anastomosis and intraperitoneal administration of irinotecan promotes the healing process of the colon anastomoses as it competes the inhibitory effect of irinotecan.
\end{abstract}

Key words: colonic anastomoses healing, irinotecan, iloprost, prostaglandins

\section{Introduction}

Irinotecan is used in the treatment of colorectal cancer, as single treatment or in combination with other cytostatic/cytotoxic agents $(1,2)$ for the destruction of cancer cells which are intraperitoneally dispersed during surgery, the inhibition of micrometastases, relapses and liver metastases (3). Its immediate postoperative, intraperitoneal administration, however, seems to negatively affect the healing of colon anastomoses (4-6).

Iloprost (ILOMEDIN ${ }^{\circledR} /$, Bayer Hellas AG) is a vasodilative and cytoprotective agent that is a structural analog of prostacyclin. By inhibiting the adhesion and aggregation of platelets and by improving microcirculation in the colon mucosa, iloprost contributes to the better oxygenation of the tissues (7-9).

Administration of iloprost, as shown in experimental data (10), promotes the healing of colonic anastomoses. Therefore, iloprost could potentially contribute to better healing of colonic anastomoses. To the best of our knowledge, this is the first experimental iloprost role assessment study to the negative effects of irinotecan in the healing of colonic anastomoses, mentioned in the literature.

The purpose of this study was to investigate the possible positive effect of iloprost in the 
anastomoses healing in rats (and by extension to human patients) which have undergone colectomy and anastomosis and are under direct intraperitoneal chemotherapy with irinotecan.

\section{Method}

\section{Animals}

Forty $(\mathrm{n}=40)$ young male Wistar rats (weighing ca. 250-300 gr) were used. The animals were provided by the experimental animal unit EL 54 BIO 23 of the Laboratory of Anatomy, Histology and Embryology, School of Veterinary Medicine, Aristotle University of Thessaloniki. The handling of animals was performed in accordance with the provisions of the European Union (Directive 2010/63/EU) and the applicable laws for the protection and proper treatment of vertebrate animals used for research and experimental purposes (Greek Laws 1197/81, 2015/92 and Presidential Decree 56/13). Experimantion received the approval of the Veterinary Directorate of Thessaloniki, Greece (approval number 426092/ 316128.01.2016).

Rats were put under general anaesthesia through an intraperitoneal administration of a mixture of ketamine $(200 \mathrm{mg} / \mathrm{kg}$ of body weight (BW) and xylazine (10 mg/kg BW). Under aseptic conditions, the abdominal cavity was accessed via a white line (linea alba) incision, $3 \mathrm{~cm}$ in length and a portion of the transverse colon, $1 \mathrm{~cm}$ in length was resected, before execution of a terminoterminal colo-colonic anastomosis by placing eight interrupted sutures of polypropylene $6 / 0$. Closure of the abdominal wall was performed in one layer with three silk sutures 3/0. After surgery, the animals were randomly divided into four equally-sized groups, with free access to food and water.

From the day of the operation until the day of sacrifice, animals were administered intraperitoneally daily the following: Group 1, $3 \mathrm{ml}$ of saline, Group 2, irinotecan at the dose of $3 \mathrm{mg} / \mathrm{kg}$ B.W., Group 3, iloprost at the dose of $2 \mu \mathrm{g} / \mathrm{kg}$ B.W., Group 4, irinotecan at the dose of $3 \mathrm{mg} / \mathrm{kg} \mathrm{B.W}$. and iloprost at the dose of $2 \mu \mathrm{g} / \mathrm{kg}$ B.W. The selection of irinotecan dose is consistent with published literature $(5,6)$ whereas the daily dose of iloprost which was used in our study is similar to the one administered to humans (11).

Rats were subjected to a daily measurement of their body weight for the exact determination of the total dose of each drug. A scheduled sacrifice of the laboratory animals took place on the $8^{\text {th }}$ post-operative day, under deep anaesthesia, with an opening of the thoracicabdominal wall and exsanguination through the right atrium.

\section{Macroscopic Examination of the Anastomoses}

During autopsy, the following were performed: macroscopic examination of the anastomosis for any existence of rupture, abscess or peritonitis and assessment of adhesions according to the Van der Hamm et al (12) scale: 0: no adhesions, 1: minimum adhesions (between the anastomosis and the omentum), 2: moderate adhesions (between the anastomosis and the small intestine), 3: severe and extensive adhesions with the creation of a perianastomotic abscess.

\section{Measurement of Bursting Pressure}

Measurement of bursting pressure was performed immediately after the sacrifice of the animals, with a $5 \mathrm{~cm}$ resection of a portion of the transverse colon with the anastomosis located directly in the center, and along with the adhesions around it. A diligent cleansing of the colon of the feces was performed before application of a pressure gauge at its distal end through a catheter which was introduced into the intestinal lumen and was stabilized using a $4 / 0$ silk suture, thus ensuring the continuous recording of the intraluminal pressure. In the proximal part of the intestinal portion, a three way catheter was placed, through which normal saline was infused at a flow of $1 \mathrm{ml} / \mathrm{min}$. The pressure was measured (in $\mathrm{mmHg}$ ) and recorded whenever there was a leakage of saline from the intestinal lumen after rupture at the anastomosis or another, 
point, away from it. It is emphasized that the rupture pressure in the animals where leakage was observed during their opening, was conventionally defined as zero (0).

\section{Histological Examination}

Having performed the measurement of the anastomosis rupture pressure, a portion of the resected intestine that bore the anastomosis, was placed in $4 \%$ formalin solution. Histological examination followed, after obtaining $3-5 \mathrm{~mm}$ thick sections with hematoxylin-eosin staining. The following were evaluated: inflammatory cell infiltration (white blood cell count), angiogenesis, neocollagen deposition and presence of fibroplasts. All the above were graded based on a Erlich and Hunt scale (13) as modified by Phillips et al (14) from 0 to 4, as follows: 0: no elements, 1: occasional elements, 2: slightly increased elements, 3: abundant elements, 4: confluent elements or fibres.

\section{Hydroxyproline Measurement}

For the determination of hydroxyproline content in the anastomosis area, a portion of the area was obtained and kept at $-80^{\circ} \mathrm{C}$. The samples, before the analysis, underwent a treatment of freeze-drying and homogenization. The principle of the analytical method was based on the hydrolysis of homogenised samples in an alkaline environment, followed by determination of the free hydroxyproline in the hydrolyzed samples according to Reddy and Enwemeka (15).

\section{Statistics}

One-way Analysis of Variance was used to detect any group (treatment) effect on continuous quantitative variables (relative body weight decrease, bursting pressure, hydroxy-proline tissue content). Nominal qualitative variables (existence of anastomotic leakage, location of rupture) were explored after construction of contingency tables. All comparisons were performed by use of Fisher's exact test. Group (treatment) effect on ordinal quantitative variables (adhesion evaluation score, inflammatory cell infiltration (white blood cell count), angiogenesis, neocollagen deposition, presence of fibroblasts ) was assessed by use of Kruskal Wallis Analysis of Variance. Significance level was set at 5\%, two-tailed. Statistical analysis was performed with the use of SPSS v. 23 software (IBM Corp., Armonk, NY, USA).

\section{Results}

All rats recovered from surgery. Statistically, a significant decrease in body weight was observed in all groups $(\mathrm{P}<0,001)$, (Table 1). The relative reduction in group 2 (irinotecan), statistically significantly differed from the reduction in groups 1 (control) $(\mathrm{P}<0.001), 3$ (iloprost) $(\mathrm{P}<0.001)$ and 4 (irinotecan with iloprost) $(\mathrm{P}<0.001)$.

The incidence of rupture and leakage of the anastomosis was considered significantly increased in group $2(\mathrm{P}=0.049)$, compared with the other groups. On the contrary, the incidence in group 4 , into which a ruptured animal was

Table 1. Relative body weight decrease $\%$ in the experimental animals

\begin{tabular}{ccccc}
\hline $\begin{array}{c}\text { Group } \\
\text { (n) }\end{array}$ & $\begin{array}{c}\text { Number of animals } \\
(\%)\end{array}$ & $\begin{array}{c}\text { Mean } \\
(\%)\end{array}$ & $\begin{array}{c}\text { Standard deviation } \\
\text { (\%) }\end{array}$ & Range \\
\hline 1 & 10 & $06.38 \mathrm{ab}$ & 2.45 & $2.44-9.93$ \\
\hline 2 & 10 & $18.06 \mathrm{acd}$ & 1.80 & $16.04-21.63$ \\
\hline 3 & 10 & $06.98 \mathrm{ce}$ & 1.38 & $5.09-8.76$ \\
\hline 4 & 10 & $13.00 \mathrm{bde}$ & 1.70 & $10.96-16.35$ \\
\hline
\end{tabular}

Group 1: control; Group 2: irinotecan; Group 3: iloprost; Group 4: irinotecan plus iloprost.

Same subscript letter indicates a significant difference for relative body weight decrease between two groups.

In total, significant differences were: group 2 compared with 1, 3 and 4, and group 4 compared with 1 and 3 . 
Table 2. Median (range) values for adhesion scores (ordinal scale) in the investigational groups, according to the scale by van der Ham et al. (1991).

\begin{tabular}{|c|c|c|}
\hline Group & $\begin{array}{l}\text { Number of animals } \\
\text { (n) }\end{array}$ & $\begin{array}{l}\text { Adhesion score } \\
\text { Median (range) }\end{array}$ \\
\hline 1 & 10 & $0.5(0-2)$ ab \\
\hline 2 & 10 & $3(2-3)$ acd \\
\hline 3 & 10 & $1(0-2) c$ \\
\hline 4 & 10 & $2(1-2) b d$ \\
\hline
\end{tabular}

Group 1: control; Group 2: irinotecan; Group 3: iloprost; Group 4: irinotecan plus iloprost. Same subscript letter indicates a significant difference for adhesion scores between two groups. In total, significant differences were: group 1 compared with 2 and 4 , and also group 2 compared with 3 and 4 .

also detected, was not considered significantly increased.

With regard to adhesions score, the application of the multiple comparisons showed that (Table 2) in group 2 (median: 3), adhesions were observed at a significantly higher degree, compared with groups 1 (median: 0.5), 3 (median: 1) and 4 (median: 2).

The bursting pressure of the anastomosis (Table 3) in group 2 was significantly lower compared with the other groups (1, 3 and 4)
$(\mathrm{P}<0.001)$. Group 4 showed a statistically significantly lower average bursting pressure compared with groups $1(\mathrm{P}=0.002)$ and 3 $(\mathrm{P}=0.001)$, while, the values of the bursting pressure in groups 1 and 3 did not significantly differ from each other $(\mathrm{P}=0.265)$. During the measurements of the rupture pressure (Table 4), rats of group 2 showed a statistically significantly $(\mathrm{P}=0.007)$ more frequent rupture of the intestinal wall in the anastomosis area (6 out of 7) compared with the rats of groups 1 ( 2 out of 10), 3 ( 1 out of 10 ) and 4 (5 out of 10 ).

Hydroxyproline levels were statistically significantly $(\mathrm{P}<0.001)$ lower in the animals of group 2 compared with the other groups (Table 5). Statistically significantly higher levels were observed in group 3 compared with groups $1(\mathrm{P}=0.004)$ and $4(\mathrm{P}=0.016)$.

Leukocytosis (Table 6) in group 2 (median: 1) was significantly reduced compared with groups 3 (median: 3) and 4 (median: 2.5) but not with group 1(median: 2). The differences between the other groups were considered as statistically non-significant.

Angiogenesis in group 2 (median: 1) was

Table 3. Bursting pressure $(\mathrm{mm} \mathrm{Hg})$

\begin{tabular}{ccccc}
\hline Group & $\begin{array}{c}\text { Number of animals } \\
(\mathbf{n})\end{array}$ & $\begin{array}{c}\text { Mean } \\
(\mathbf{m m H g})\end{array}$ & $\begin{array}{c}\text { Standard deviation } \\
(\mathbf{m m H g})\end{array}$ & $\begin{array}{c}\text { Range } \\
(\mathbf{m m H g})\end{array}$ \\
\hline 1 & 10 & $284.00 \mathrm{ab}$ & 32.72 & $235-330$ \\
\hline 2 & 10 & $87.10 \mathrm{acd}$ & 63.24 & $0-165$ \\
\hline 3 & 10 & $317.10 \mathrm{ce}$ & 31.27 & $285-375$ \\
\hline 4 & 10 & $231.60 \mathrm{bde}$ & 24.42 & $195-266$ \\
\hline
\end{tabular}

Group 1: control; Group 2: irinotecan; Group 3: iloprost; Group 4: irinotecan plus iloprost.

Same subscript letter indicates a significant difference for adhesion scores between two groups.

In total, significant differences were: group 2 compared with 1, 3 and 4, and group 3 compared with 4 .

Table 4. Location of leakage during bursting pressure measurement

\begin{tabular}{cccc}
\hline Group & $\begin{array}{c}\text { Total number } \\
\text { of animals examined } \\
(\mathbf{n})\end{array}$ & $\begin{array}{c}\text { Animals with leakage } \\
\text { at the anastomosis site } \\
(\mathbf{n})\end{array}$ & $\begin{array}{c}\text { Animals with leakage at site other } \\
\text { than the anastomosis } \\
(\mathbf{n})\end{array}$ \\
\hline 1 & 10 & $2 \mathrm{a}$ & $8 \mathrm{a}$ \\
\hline 2 & 07 & $6 \mathrm{abc}$ & $1 \mathrm{abc}$ \\
\hline 3 & 10 & $1 \mathrm{~b}$ & $9 \mathrm{~b}$ \\
\hline 4 & 10 & $5 \mathrm{c}$ & $5 \mathrm{c}$ \\
\hline
\end{tabular}

Group 1: control; Group 2: irinotecan; Group 3: iloprost; Group 4: irinotecan plus iloprost.

Same subscript letter indicates a significant difference for the location of leakage between two groups.

Animals of group 2 displayed leakage close to anastomosis significantly more often that animals in the other groups. 
Table 5. Hydroxyproline levels in the tissue segment surrounding the anastomosis site.

\begin{tabular}{ccccc}
\hline Group & $\begin{array}{c}\text { Number of animals } \\
(\mathbf{n})\end{array}$ & $\begin{array}{c}\text { Mean } \\
(\mu \mathrm{g} / \mathrm{mg} \text { tissue })\end{array}$ & $\begin{array}{c}\text { Standard deviation } \\
(\mu \mathrm{g} / \mathrm{mg} \text { tissue })\end{array}$ & $\begin{array}{c}\text { Range } \\
(\mu \mathrm{g} / \mathrm{mg} \text { tissue })\end{array}$ \\
\hline 1 & 10 & $2.39 \mathrm{ab}$ & 0.57 & $1.47-2.85$ \\
\hline 2 & 10 & $1.39 \mathrm{acd}$ & 0.27 & $0.86-1.62$ \\
\hline 3 & 10 & $3.64 \mathrm{bce}$ & 0.76 & $2.24-4.49$ \\
\hline 4 & 10 & $2.62 \mathrm{de}$ & 0.48 & $2.02-3.34$ \\
\hline
\end{tabular}

Group 1: control; Group 2: irinotecan; Group 3: iloprost; Group 4: irinotecan plus iloprost.

Same subscript letter indicates a significant difference for hydroxyproline levels between two groups.

In total, significant differences were: group 1 compared with 2 and 3, group 2 compared with 3 and 4, and group 3 with 4.

Table 6. Median (range) values for histopathology (ordinal scale) variables in the investigational subgroups, according to the scale proposed by Ehrlich and Hunt (1969), as modified by Phillips et al. (1992)

\begin{tabular}{|c|c|c|c|c|c|}
\hline Group & $\begin{array}{l}\text { Number of animals } \\
(\mathrm{n})\end{array}$ & $\begin{array}{l}\text { Inflammatory } \\
\text { cell infiltration }\end{array}$ & Angiogenesis & $\begin{array}{l}\text { Neocollagen } \\
\text { deposition }\end{array}$ & $\begin{array}{r}\text { Fibroblast } \\
\text { presence }\end{array}$ \\
\hline & & \multicolumn{4}{|c|}{ Median (range) } \\
\hline 1 & 10 & $2(1-4)$ & $2(1-3)$ a & $2(1-3) a$ & $2(1-3) a$ \\
\hline 2 & 10 & $1(0-3) a b$ & $1(0-3) b c$ & $0(0-2) a b c$ & $1(0-2) a b c$ \\
\hline 3 & 10 & $3(1-4)$ a & $3(3-4) a b$ & $3(2-4) b$ & $2.5(1-4) b$ \\
\hline 4 & 10 & $2.5(1-4) b$ & $3(1-4) c$ & $3(1-3) c$ & $2.5(1-3) c$ \\
\hline
\end{tabular}

Group 1: control; Group 2: irinotecan; Group 3: iloprost; Group 4: irinotecan plus iloprost.

Same subscript letter indicates a significant difference between two groups.

In total, significant differences were: for inflammatory cell infiltration, group 2 with 3 and 4; for angiogenesis, group 1 with 3 ,

and group 2 with 3 and 4; for neocollagen deposition, group 2 compared with all others; for fibroblast presence, group 2 with 1, 3 and 4 .

significantly lower compared with groups 3 (median: 3) and 4 (median: 3), but not compared with group 1 (median: 2). Group 1 (median: 2) statistically significantly differed from group 3 (median: 3). The difference between groups 3 and 4 (median: 3) were considered as non-significant. The degree of neocollagen deposition in group 2 (median: 0) was significantly lower compared with groups 1 (median: 2), 3 (median: 3) and 4 (median: 3). All other comparisons showed no significant differences.

The presence of fibroblasts was significantly reduced in group 2 (median: 1) compared with groups 1 (median: 2), 3 (median: 2.5) and 4 (median: 2.5). The presence of fibroblasts did not statistically significantly differ between the other groups.

\section{Discussion}

After performing of a colectomy for colon cancer, irinotecan can be administered combinatorially in various chemotherapy regimens as well as a monotherapy in order to address potential micrometastases $(16,17)$. In a multi-center research by Fuchs et al (18), it was shown that the combination of irinotecan, 5 fluorouacil and leucovorin (19) can significantly lengthen the life of patients suffering from metastatic colorectal cancer, compared with patients receiving 5 fluorouacil and leucovorin only. From the same study, it appears that regimens based on irinotecan can and actually enable the resection of liver metastases and hence the average survival of patients further improves.

The intraperitoneal route of administration of a chemotherapeutic drug has the tactical advantage that high concentrations of the drug itself are achieved in the peritoneal cavity and liver, without observing the toxicity associated with systemic administration. On the other hand, the healing process can be significantly inhibited and therefore a rupture in the colon anastomoses may occur (20).

According to Pramateftakis et al $(5,6)$, the 
direct intraperitoneal administration of irinotecan adversely affects the healing process of anastomoses in the colon after a colectomy. More specifically, the mechanical strength of the anastomosis is reduced, a fact that can be deduced by the increased frequency of rupture and the reduction of the anastomotic rupture pressures which was also confirmed in our study.

A statistically significantly greater decrease in the average body weight of the rats treated intraperitoneally with irinotecan after colectomy has been mentioned in very few studies $(5,6)$. In our study, the weight loss was significantly greater $(\mathrm{P}<0.001)$ in group 2 compared with group 1.

Pramateftakis et al (6) have mentioned a statistically significant reduction $(\mathrm{P}<0,001)$ of the average bursting pressure in the irinotecan group compared with their control group. In our study, the anastomosis bursting pressure was statistically significantly lower $(\mathrm{P} \leq 0,001)$ in the irinotecan group, compared with all other groups.

Rupture of the intestinal wall in the animals of group 2 occurred significantly more often $(\mathrm{P}=0.007)$ in the anastomosis area compared with the other groups. This is consistent with a reference by Pramateftakis et al (5).

Adhesions at a significantly greater degree compared with the other groups were observed in group 2. This is attributed to the micro-leakages of the anastomoses brought about by the administration of irinotecan and their entrenchments with adhesions. In another study in rats, Pramateftakis et al (6) also demonstrated a statistically significant difference in the adhesion score in the irinotecan group compared with the control group $(\mathrm{P}<0,001)$.

Leukocytosis in group 2 was significantly reduced compared with groups 3 and 4 . Angiogenesis in group 2 was also significantly lower compared with groups 3 and 4 . In the irinotecan group, a statistically significant reduction of the fibroblasts and neocollagen was observed. Pramateftakis et al (5) have mentioned that the intraperitoneal administration of irinotecan in rats leads to statistically significantly reduced levels of hydroxyproline in anastomoses. In our study, it was found that statistically significantly reduced hydroxy-proline levels were observed in group 2 compared with group $1(\mathrm{P}=0.001)$. In the few studies on the effect of irinotecan on the healing mechanism, there are references for the in vitro culture of human fibroblasts and the inhibition of collagen biosynthesis by camptothecin (21, 22).

Iloprost is a structural analogue of the endogenous prostacyclin (PGI2) (23) with a strong vasodilatory action that decreases the rate of cellular apoptosis of the epithelial mucosal cells. Its cellular receptors are located throughout the gastrointestinal mucosa. In an experimental study, Cutler et al (24) have mentioned cells of the fibrous substrate of the intestinal mucosa producing endogenous prostacyclin. Lee et al (25) demonstrated that prostacyclin plays an important role in the cytoprotection and vascularization of the gastrointestinal tract, whereas Wang et al (26) have reported a strengthening of the healing process in the gastrointestinal mucosa, following the administration of prostacyclin, which promotes the migration of the epithelial cells.

Administration of iloprost in group 4 caused a statistically significant reduction in the leakage frequency in the anastomoses compared with group $2(\mathrm{P}=0.007)$. By adding iloprost to group 4, a statistically significant decrease in the degree of adhesions occurred, compared with group 2. Therefore, the addition of iloprost most likely inhibited the emergence of micro-leakages inflicted by the effect of irinotecan and therefore the degree of subsequent adhesions reduced.

In an experimental study of Hilan et al. (27), it has been reported that the best criteria for the evaluation of the anastomotic healing of the colon are the macroscopic necrotomic findings. To assess the strength of colonic anastomoses, the most reliable method is considered to be the measurement of their bursting pressure $(28,29)$. In a study in rats, Bostanoglou et al. (30) have mentioned that the administration of iloprost caused no statistically significant increase in the bursting 
pressure of the colon anastomoses. In our study, through the administration of iloprost in group 4, statistically significantly increased values in the bursting pressure of the anastomoses compared with group $2(\mathrm{P}<0.001)$ were observed. Also, during the bursting pressure measurement test, the rupture in group 4 took place away from the anastomosis site, at a percentage of $50 \%$ (5/10 animals), presumably due to the increased strength of anastomoses in this group, compared with group 2 , in which rupture took place at the anastomosis site at a percentage of $87.5 \%(6 / 7$ animals $)$. This difference was statistically significant $(\mathrm{P}=0.007)$.

The histological findings after the intraperitoneal post-operative administration of iloprost were significantly improved. Our data showed a statistically significant increase in fibroblasts in group 4, as compared to group 2 , whereas, regarding neocollagen deposition, there was also a significant increase. Consequently, the increased mechanical strength in the group 4 anastomoses may be attributed to the activation and the increased deposition of collagen in the anastomosis area. Based on these findings, it is evident that the administered iloprost significantly competed the negative effect of irinotecan in the synthesis of collagen.

Inflammation plays a central role in the regulation of the anastomoses healing. In the inflammatory phase, the white blood cells are involved in the mobilization and activation of the fibroblasts and epithelial cells (31). Czeslick et al (32) showed that prostacyclin produced by the inflammatory cells is part of an important physiological feedback mechanism. Moreover, Lehmann et al (33) proved that iloprost reduced the adhesion of leukocytes to the venous endothelium of the sub-mucosal tissue of the colon. In our study, what was found was a statistically significant increase of leukocyte count in group 4, compared with group 2 , a fact which indicates that iloprost promoted the inflammatory phase process.

In recent years, there has been an increasing recognition of the value of the interdependent relationship between iloprost and angiogenesis. Pola et al (34) showed that iloprost induces angiogenesis through a vascular endothelial growth factor-dependent mechanism, and that the activity of the vascular endothelial growth factor is essential for the angiogenesis induced by iloprost. In similar studies, it has been documented that PGI2 represents an essential mediator of the angiogenesis induced by kallikrein, and that angiogenesis through alpha $\mathrm{v}$ beta 3 is caused partially by the inductive action of PGI2 (35, 36). In our study, a statistically significant increase of angiogenesis in group 4 compared with group 2 was observed, indicating that the administered iloprost can reverse the negative effect of irinotecan.

\section{Conclusions}

Intraperitoneal administration of iloprost after colectomy, termino-terminal anastomosis and intraperitoneal administration of irinotecan promotes the healing process of the colon anastomoses as it competes the inhibitory effect of irinotecan.

\section{Acknowledgements}

We particularly thank the Emeritus Professor of Surgery of the Aristotle University of Thessaloniki Mr. Charalambos Spyridis, for his multiple and meaningful contribution both to the assignment of the study and its completion. He took care both for the design of the protocol and for the proper execution of the experimental part and the writing of the work.

\section{Conflicts of Interest}

No authors have any conflict of interest with the manufacturer of iloprost (ILOMEDIN /, Bayer Hellas AG).

\section{References}

1. Kuramochi $\mathrm{H}$, Ando $\mathrm{M}$, Itabashi $\mathrm{M}$ et al. Phase II study of bevacizumab and irinotecan as second-line therapy for patients with metastatic colorectal cancer previously treated with fluoropyrimidines, oxaliplatin, and bevacizumab.Cancer Chemother Pharmacol2017; 79(3): 579-85. doi: 10.1007/s00280-017-3255-3.

2. Hashida H, Satake H, Kaihara S. A complete response case in a 
patient with multiple lung metastases of rectal cancer treated with bevacizumab plus XELIRI Therapy.Case Rep Oncol 2017; 10(1): 81-5. doi: 10.1159/000455899.

3. Scevola G, Loreni G, Rastelli M, Sposato S, Ramponi S, Miele V. Third-line treatment of colorectal liver metastases using DEBIRI chemoembolization. Med Oncol 2017; 34(3): 37.doi: 10.1007/ s12032-017-0890-9.

4. Nerstrøm M, Krarup PM, Jorgensen LN, Tgren MS. Therapeutic improvement of colonic anastomotic healingunder complicated conditions: A systematic review.World J Gastrointest Surg 2016; 8(5): 389-401.doi:10.4240/wjgs.v8.i5.389.

5. Pramateftakis MG, Kanellos D, Mantzoros I et al. Intraperitoneally administered irinotecan with 5-fluorouracil impair wound healing of colonic anastomoses in a rat model:an experimental study. Tech Coloproctol 2011; Suppl1: S121-5.

6. Pramateftakis MG, Kanellos D, Demetriades $\mathrm{H}$ et al. The effects of irinotecan on the healing of colonic anastomoses in rats. The Open Surgery Journal2007;1:1-6.doi: 10.2174/1874300500701010001.

7. Johansson PI, Mortensen CR, Nielsen T et al. The effect of intraoperative and 6-h postoperative intravenous administration of low-dose prostacyclin on the endothelium, hemostasis, and hemodynamics in patients undergoing a pancreaticoduodenoctemy: a randomized-controlled pilot study.Eur J Gastroenterol Hepatol 2017; 29(4): 400-6. doi: 10.1097/MEG.0000000000000800.

8. Galanopoulos G, Raptis D, Pramateftakis MG, Mantzoros I, Kanellos I, Lazarides C. The effects of iloprost on colonic anastomotic healing in rats under obstructive ileus conditions. J Surg Res 2014; 189(1): 22-31. doi: http://dx.doi.org/10.1016/j.jss.2014. 01.052.

9. Oines MN, Krarup PM, Jorgensen LN, Argen MS. Pharmacological interventions for improved colonic anastomotic healing: a meta-analysis. World J Gastroenterol 2014; 20(35): 12637-48. doi: 10.3748/wjg.v20.i35.12637.

10. Vasiliadis K, Kanellos I, Tsachalis T et al. Influence of the stable prostacyclin analog iloprost on the healing of colonic anastomosis in rats.Minerva Chir 2007; 62(4): 241-8.

11. Banyai $S$, Jenelten $R$, Wagner $S$, Allmann $J$, Banyai $M$, Koppensteiner R. Outpatient treatment of severe peripheral ischemia with intravenous intermittent low-dose iloprost. An open pilot study. Int Angiol 2002; 21: 36-43.

12. Van der Ham AC, Kort WJ, Weijma IM, van den Ingh HF, Jeekel J. Effect of fibrin sealant on the healing colonic anastomosis in the rat. Br J Surg 1991; 78: 49-53.

13. Ehrlich HP, Hunt TK. The effects of cortisone and anabolic steroids on the tensile strength of healing wounds. Ann Surg 1969; 170: 203-6.

14. Philips JD, King CS, Fonkalsrud EW, Zeng H, Dindar H. Effects of chronic corticosteroid and vitamin $A$ on the healing of intestinal anastomoses. Am J Surg 1992; 163: 71-7.

15. Reddy CG, Enwemeka CS. A simplified method for the analysis of hydroxyproline in biological tissues. Clin Biochem 1996; 29(3): 225-9.

16. Saltz LB, Cox JV, Blanke $C$ et al. Irinotecan plus fluorouracil and leucovorin for metastatic colorectal cancer. Irinotecan Study Group. N Engl J Med 2000; 343(13): 905-914.

17. Douillard JY, Cunningham D, Roth AD et al. Irinotecan combined with fluorouracil compared with fluorouracil alone as first-line treatment for metastatic colorectal cancer:a multicentre randomized trial. Lancet 2000; 355: 1041-7.

18. Dahm AE, Andersen TO, Rosendaal F, Sandset PM. A novel anticoagulant activity assay of tissue factor pathway inhibitor I (TFPI). J Thromb Haemost 2005; 3(4): 651-8. doi: 10.1111/j.1538- 7836.2005.01237.x

19. Francois $E$, Berdah JF, Chamorey $E$ et al. Use of the folinic acid/5fluorouracil/irinotecan (FOLFIRI 1) regimen in elderly patients as a first-line treatment for metastatic colorectal cancer: a Phase II study. Cancer Chemother Pharmacol 2008; 62(6): 931-6. doi: 10.1007/s00280-008-0681-2.

20. Kanellos I, Kavouni A, Zaraboukas T, Odisseos C, Galovatsea K, Dadoukis I. Influence of intraperitoneal 5 -fluorouracil plus folinic acid on the healing of colonic anastomoses in rats. Eur Surg Res 1996; 28: 374-9. doi:10.1159/000129479.

21. Miltyk W, Karna E, Palka JA. Prolidase-independent mechanism of camptothecin-induced inhibition of collagen biosynthesis in cultured human skin fibroblasts. J Biochem 2007; 141: 287-92. doi:10.1093/jb/mvm022.

22. Zhang GY, Gao WY, Li X et al. Effect of camptothecin on collagen synthesis in fibroplasts from patients with keloid. Ann Plast Surg 2009; 63(1):94-9. doi:10.1097/SAP.0b013e3181872775.

23. Vane J, Corin RE. Prostacyclin: a vascular mediator. Eur J Vasc Endovasc Surg 2003; 26(6): 571-8. doi: 10.1016/S1078.

24. Cutler NS, Graves-Deal R, LaFleur BJ et al. Stromal production of prostacyclin confers an antiapoptotic effect to colonic epithelial cells. Cancer Res 2003; 63(8):1748-51.

25. Lee SH, Soyoola E, Chanmungam P et al. Selective expression of mitogen-inducible cyclooxygenase in macrophages stimulated with lipopolysaccharide. J Biol Chem 1992; 267(36): 25934-8.

26. Wang D, Mann JR, Dubois RN. The role of prostaglandins and other eicosanoids in the gastrointestinal tract. Gastroenterology 2005; 128(5): 1445-61. doi: http://dx.doi.org/10.1053/j.gastro. 2004.09.080

27. Hillan K, Nordlinger B, Ballet F, Puts JP, Infante R. The healing of colonic anastomoses after early intraperitoneal chemotherapy. An experimental study in rats. J Surg Res 1988; 44: 166-71.

28. Hendriks T, Mastboom WJ. Healing of experimental intestinal anastomosis: parameters for repair. Dis Colon Rectum 1990; 33(10): 891-901.

29. Witte MB, Barbul A. Repair of full-thickness bowel injury. Crit Care Med 2003; 31: 538S-546S.

30. Bostanoglu S, Dincer S, Keskin A, Bostanoglu A, Dursun A, Serim C. Beneficial effect of lloprost on impaired colonic anastomotic healing induced by intraperitoneal 5 -fluorouracil infusion. Dis Colon Rectum 1998; 41(5): 642-8.

31. Park JE, Barbul A. Understanding the role of immune regulation in wound healing. Am J Surg 2004; 187(5A):11S-16S.

32. Czeslick EG, Simm A, Grond S, Silber RE, Sablotzki A. Inhibition of intracellular tumour necrosis factor (TNF) alpha and interleukin (IL)-6 production in human monocytes by iloprost. Eur J Clin Invest 2003; 33(11): 1013-7.

33. Lehmann C, Konig JP, Dettmann J, Birnbaum J, Kox WJ. Effects of iloprost, a stable prostacyclin analog, on intestinal leucocyte adherence and microvascular blood flow in rat experimental endotoxemia. Crit Care Med 2001; 29: 1412-6.

34. Pola $\mathrm{R}$, Gaetani E, Flex $\mathrm{A}$ et al. Comparative analysis of the in vivo angiogenic properties of stable prostacyclin analogs: a possible role for peroxisome proliferatoractivated receptors. J Mol Cell Cardiol 2004; 36: 363-70.

35. Knighton DR, Hunt TK, Scheuenstuhl H, Halliday BJ, Werb Z, Banda MJ. Oxygen tension regulates the expression of angiogenesis factor by macrophages. Science 1983; 221: 1283-5. doi: 10.1126/ science.6612342.

36. Tonnesen MG, Feng $X$, Clark RA. Angiogenesis in wound healing. $J$ Investig Dermatol Symp Proc 2000; 5(1): 40-46. doi: 10.1046/ j.1087-0024.2000.00014.x 